\title{
Assessment of regional changes for enhancing water availability
}

\author{
Jay Krishna Thakur ${ }^{1,3^{*}} \mathbb{D}$, Kapil Khanal ${ }^{2}$ and Kabita Poudyal ${ }^{1}$
}

\begin{abstract}
Background: The land use plays a crucial role for a particular watershed along with many other identified and accepted factors. Momentarily, land cover practices are unorganised in most river basins of Nepal. The study aims at land cover classification, mapping of the changes over the last 25 years, an assessment of the accuracy for land cover classification, consolidation of the people's perception of the ongoing work, studying trends in the temperature and precipitation pattern in the last 30 years in the area composed by 4 watersheds of the districts of Kaski and Tanahun of Chitwan Annapurna Landscape region, Nepal.

Results: This research depicted that the land cover practice is changing in the areas of study. In most of the cases, the share of open broadleaved forest is higher. In case of closed broadleaved forest, it has improved in the recent years. Chhabdi Khola and Guhe Khola watersheds show an increase in overall forest cover and decrease in percentage of agricultural lands. Overall, despite changing climate, rise of temperature and declining of rainfall pattern, the vegetation cover shows an increasing tendency which may have positive effects for the water availability in the Kaski and Tanahun regions.

Conclusions: The following research endeavoured to connect knowledge and people's perception in order to understand the implications related to land use management and possibly to improve water availability for society. The investigation includes integrated land use changes, vegetation cover, climatic trends and potential of this knowledge implementation for local people, farmers, regional and national governing agencies.
\end{abstract}

Keywords: Enhancing water availability, Regional change monitoring, Chitwan Annapurna landscape region, Chhabdi Khola, Guhe Khola watersheds, Nepal

\section{Background}

Land use planning plays an integral role in sustainable conservation and management of catchment's specific resources (van Lier 1998). Catchment's properties determine various sub-parameters that play an important role in the water budget within the catchment (Atkinson 2002). The intricate relationship between vegetation and water cycle in a micro-catchment defines the water cycle in the basin, which in turn redefines the growth and productivity of the plant species (Thakur et al. 2012; Li et al. 2013; UIZ 2015). Similarly, the nature of the soil and its spatial distribution also affect the basin's response

\footnotetext{
*Correspondence: info@hems.org.np

${ }^{3}$ UIZ Umwelt und Informationstechnologie Zentrum GmbH,

Neue Grünstraße 38, 10179 Berlin, Germany

Full list of author information is available at the end of the article
}

to water availability (Schmidt et al. 2011; Thakur 2011). However, this relationship has failed to be understood by many management interventions and planning policy needs. Momentarily, land cover/land use practices are unorganised in most (smaller) river basins of Nepal. Although the target for maintenance of fixed $40 \%$ of forest resources is made by goals and policies in Nepal, there is often a lack of the mechanisms for sound delineation of the requisite areas to achieve the balanced ecological function of nature (Tamrakar 2004).

Land cover verification to assess the state of accuracy in terms of real ground scenario can provide an estimation of the accuracy with which classification was performed. Studies of the land cover shift are also valuable for analysis of the environmental impact of human activities, climate change and other forces (Singh 2011). Such analysis 
can be useful due to providing information that can help to resolve the conflicts between human use of natural resources and the foundation of the natural system.

In parallel with the modifications in the land cover practices, other types of changes were occurring in the area. Thus, the analysis of some climate values (temperature-maximum, minimum and mean- and rainfalltotal, annual and seasonal-) provides a useful insight into the influence of climate change (Shrestha and Aryal 2011). Due to the change in land use/cover, the spread of water drainage is expected in the watershed with changing frequency and intensity of the runoff generated due to rainfall.

Land use/cover on the surface of the earth undergoes changes over time. In any watershed, the surface and subsurface runoff are functions of physical, biological as well as anthropogenic contributory factors (Merz et al. 2006; Ghimire et al. 2014). On the basis of review and in-depth analysis of existing physical, biological and socioeconomic setting of the area, the model depicting interrelationship operating in the area can be tentatively materialised in response to the land use practices (Pielke et al. 2007). Land use/cover plays a crucial role along with many other identified and assumed factors for a particular watershed. Thus, there was necessity to include the parameters related to and applicable in the area of interest. Increased knowledge about the interaction between conservation of natural resources, influence of forest, conservation of water availability in the catchment and perception of local peoples' participation in conservation activities are integrated components (Schmithüsen and Wild-Eck 2000; Dolisca et al. 2007).

This study aims at assessing the changes in land use, climatic variation integrating with availability of water in the research area. Moreover, the investigation is set to classify the land cover of the study area, map and assess the change in land cover over the last 25 years, assess the accuracy for land cover classification, study changes in temperature and precipitation pattern in the last 30 years in relation with present water availability in the research area.

\section{Study area}

The study has been conducted in 4 watersheds of 2 districts of Chitwan Annapurna Landscape (CHAL) region. Tanahun district comprised Chhabdi Khola and Guhe Khola watersheds, whereas Kaski district comprised Gharmi and Bhoti Khola watersheds. The locations of the specific watersheds in the respective districts are depicted by Fig. 1.

\section{Methods}

In order to assess the current status of vegetation cover and other land use categories and make a comparison with the previous years, detailed land cover mapping of 4 watersheds in Tanahun and Kaski districts has been accomplished. The trend of climatic changes during the last 30 years in the area was analysed with the help of trend analysis of temperature and rainfall. People's perception of the on-going work played an important role in the study. As the last step, the final assessment of regional changes has been done in order to form the basis for understanding the relationship between water availability, vegetation cover and climate and to draw recommendation for enhancing water availability (Fig. 2).

\section{Land cover mapping and accuracy assessment/verification of the land cover map}

The land use classification method was supervised Maximum Likelihood Classification (Strahler 1980) for 1990, 1995, 2000, 2005, 2010 and 2015 using LANDSAT and SENTINEL data.

The methodology for accuracy assessment incorporated is both primary and secondary sources of information (Foody 2002). Field observation was the basis of the study with a Global Positioning System (GPS) Garmin navigation device, used for collecting the ground truths primary data for verification. A total of 38 ground trothing points was collected using Garmin GPS device in different land use/land cover. Kappa coefficient was calculated along with overall accuracy. Producer's accuracy and user's accuracy were also similarly determined (Keninger 2012).

$$
\begin{aligned}
& \text { Accuracy }_{\text {Total }}=\frac{\text { Total of all similar category plots in reference and classified map }}{\text { Total plots }} \times 100 \% \\
& \text { Accuracy }_{\text {User, } \text { specified class }}=\frac{\text { Plots where class is correctly determined }}{\text { Total plots for that class in classified map }} \times 100 \% \\
& \text { Accuracy }_{\text {Producer, } \text { specified class }}=\frac{\text { Plots where class is correctly determined }}{\text { Total plots for that class in reference map }} \times 100 \%
\end{aligned}
$$




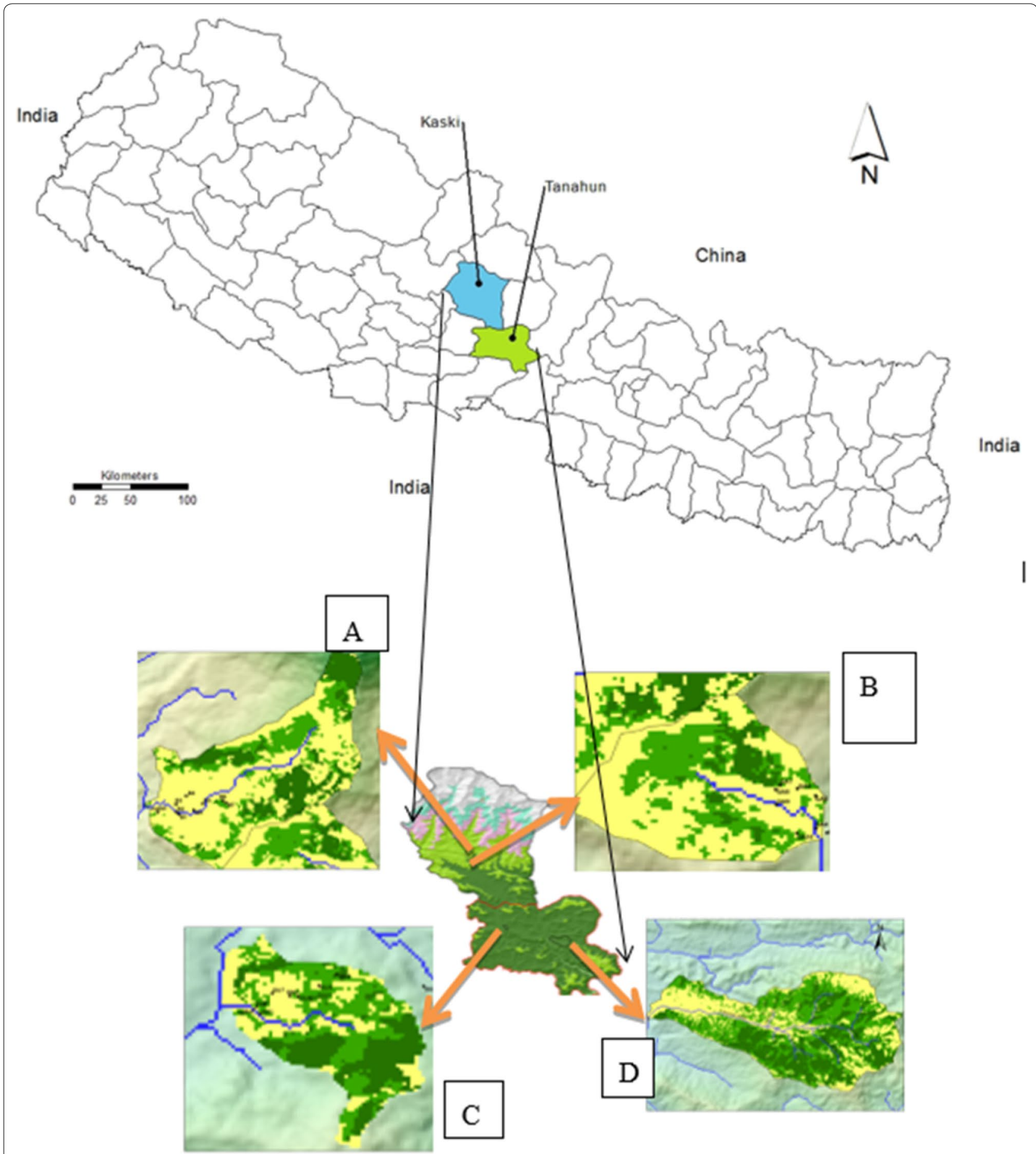

Fig. 1 Study area illustrating research districts with watersheds A Bhoti Khola watershed; B Gharmi Khola watershed; C Guhe Khola watershed; D Chhabdi Khola watershed

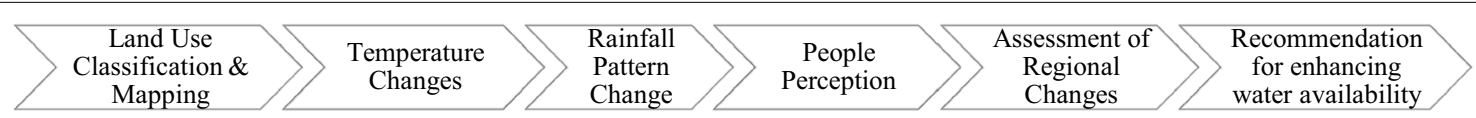

Fig. 2 Flow chart for the regional changes assessment and recommendation for enhancing water availability 


\section{Temperature and rainfall changes during 1985-2014 year (30 years)}

Analysis of climatic trend has been carried out with the help of temperature and precipitation data for 30 years from the available stations. The stations have been selected in response to their locations within the basin and/or close surroundings with the basin. The trend analysis has been made for 30 years' available data from the stations. The details of stations and data availability are presented in Table 1.

For temperature trend analysis, the average annual temperature has been calculated using the available data from monthly temperature values. The annual temperature trend has been carried out for maximum temperature $(\operatorname{tmax})$, minimum temperature (tmin) and mean temperature (tmean) for each of the stations, i.e. Pokhara airport, Khairenitar and Damauli. Similarly, the precipitation trend has been estimated by calculation of total annual rainfall from monthly precipitation from January to December.

\section{Field survey}

The fields visit in pre- and the post-monsoon season was conducted during the study. The main tasks pertaining to the field investigation were as below:

1. Observation of the field-specific conditions of the watersheds.

2. Collection of data at specified points for verification of the land use maps.
3. Measurement of field specific parameters like soil temperature, ambient air temperature and relative humidity.

\section{People's perception}

The purpose of the people's perception meetings (Table 2) was to retrieve information from various concerned sectors as well as cross-sectors regarding their perception, participation and efforts for understanding the influence of land use on the water availability in the area. Participatory personnel were the key informants from various sectors such as forestry, soil conservation, water supply and management etc. Simultaneously, the meetings aimed to incorporate experiences and knowledge of the local people residing in the area in order to account for the experiences and learning that they have gathered on the basis of their general understandings.

In the people's perception meetings, the information about types of forest, vegetation types (e.g. name of species, type of occurrence), agro-biodiversity, soil information, agricultural land information, information pertaining to community forest user groups in the area, questions related to water supply and their relocation to land use changes, information regarding irrigation water supply and water bodies were collected. The participants at the people's perception meetings were stakeholders from school level teachers and guardians; district level governmental and non-governmental officers; public participatory groups; social leaders and concerned groups; small scale business operators; and the general public.

Table 1 Details of meteorological stations for climatic data

\begin{tabular}{llllll}
\hline S. N. & Name of the station & Catchment representation & $\begin{array}{l}\text { Location coordinates } \\
\text { (lat, long, altitude) }\end{array}$ & Data types available & $\begin{array}{l}\text { Period of data available } \\
\text { for use }\end{array}$ \\
\hline 1 & Pokhara airport & Gharmi-Bhoti & $28^{\circ} 13^{\prime} ; 84^{\circ} 00^{\prime} ; 0827 \mathrm{~m}$ & Precipitation, temperature & $1985-2014(30$ years) \\
2 & Khairenitar & Guhe & $28^{\circ} 02^{\prime} ; 84^{\circ} 06^{\prime} ; 0500 \mathrm{~m}$ & Precipitation, temperature & $1985-2014(30$ years) \\
3 & Damauli & Chhabdi & $27^{\circ} 58^{\prime} ; 84^{\circ} 17^{\prime} ; 0358 \mathrm{~m}$ & Precipitation, temperature & $(1985-2014)(30$ years) \\
4 & Lamachaur & Gharmi-Bhoti & $28^{\circ} 16^{\prime} ; 83^{\circ} 58^{\prime} ; 1070 \mathrm{~m}$ & Precipitation & $1985-2014(30$ years) \\
\hline
\end{tabular}

Table 2 People's perception information meetings were organised on following date and location

\begin{tabular}{llll}
\hline S. N. & Name of watershed & Date & Place \\
\hline 1. & Chhabdi & 03.06 .2015 & DFS School, Byas Municipality-02, Tanahun, Nepal \\
2. & Guhe & 04.06 .2015 & Saunepani, Chhang V.D.C., Tanahun \\
3. & Gharmi/Bhoti & 05.06 .2015 & IOF, Pokhara, Kaski, Nepal \\
4. & Gharmi/Bhoti & 05.06 .2015 & WWF Office, New Road, Pokhara, Kaski \\
5. & Gharmi/Bhoti & 09.06 .2015 & Shree Dhara Pra. Bi. School, Churung, Puranchaur-05, Kaski, Nepal \\
6. & Chhabdi & 04.12 .2015 & Satyabati Higher Secondary School, Byas Municipality-02, Tanahun, Nepal \\
7. & Gharmi/Bhoti & 08.12 .2015 & Puranchaur-06, Kaski, Nepal \\
\hline
\end{tabular}




\section{Results and discussion}

The following results were obtained and analysed with the aim of meeting the goals and objectives of the project.

\section{Land cover classification and mapping}

The outlet point location of Bhoti Khola watershed in Kaski district is $83^{\circ} 57^{\prime} 5.888^{\prime \prime}$ E longitude and $28^{\circ} 17^{\prime} 17.982^{\prime \prime} \mathrm{N}$ latitude, while the outlet point location of the Gharmi Khola watershed is $83^{\circ} 58^{\prime} 57.102^{\prime \prime} \mathrm{E}$ longitude and $28^{\circ} 16^{\prime} 33.021^{\prime \prime} \mathrm{N}$ latitude. Guhe Khola is located in the western part of Tanahun district represented by latitude of $84^{\circ} 5^{\prime} 53.083^{\prime \prime} \mathrm{E}$ and $28^{\circ} 0^{\prime} 50.063^{\prime \prime} \mathrm{N}$ whilst the Chhabdi Khola located at the eastern part of Tanahun has point location represented by $84^{\circ} 16^{\prime} 37.048^{\prime \prime} \mathrm{E}$ and $27^{\circ} 57^{\prime} 51.994^{\prime \prime} \mathrm{N}$. Chhabdi Khola has the largest catchment area of the four study areas with an area of about $28.4 \mathrm{~km}^{2}$. Guhe Khola has the smallest catchment area with about $2.3 \mathrm{~km}^{2}$. The Bhoti Khola catchment area is about $6 \mathrm{~km}^{2}$ and the Gharmi Khola catchment area about $3 \mathrm{~km}^{2}$. The details of each of the watersheds are presented in Table 3.

Land cover mapping has been done for various years in order to track the changes occurring in the area for the subsequent years. Results obtained for various watersheds are further described.

\section{Chhabdi Khola watershed}

Figure 3 provides the land cover map of Chhabdi Khola basin for the year 2015. Included in the map are the points of samples for purpose of land-use verification in the watershed. The sampling points will be used as a basis for the verification of land cover maps obtained through classification processes (in the preceding stage).

Land cover change analysis for Chhabdi Khola watershed from year 1990 until year 2015 is depicted by Fig. 4:

As can be observed, the Chhabdi Khola river basin is an area largely covered by (open and closed) forest (fluctuating at around a little over $60 \%$ of the total area from 1990 to 2015). There is generally more open than the closed broadleaved forest in the season during which the classifications were made. There is a strong probability that the percentage of the closed broadleaved forest class will rise significantly in the monsoon season, since the canopy will get denser in the wetter season (this also applies to the other study areas). The share of open broadleaved forest peaked in 2000 with $41.86 \%$, while the share of the closed broadleaved forest was at its lowest. In contrast, while the share of the closed broadleaved forest peaked in 2010 with $30.77 \%$ the share of the closed broadleaved forest was at its lowest with $31.35 \%$.

Most of the agricultural area is located in the downstream of Chhabdi Khola, and in the north and southeast. As can be observed when examining figure and graph, the agricultural area in the Chhabdi Khola river basin is fluctuating around the mid $30 \%$. The agricultural land increased from $34.68 \%$ in 1990 to $38.61 \%$ in 1995 , and then decreased to $35.26 \%$ in 2000 . Subsequently, there is an increase in agricultural land from 2000 to 2010 (from $35.26 \%$ in 2000 to $36.62 \%$ in 2005 , followed by a further increase to $37.88 \%$ in 2010). Finally, there is a decrease of over 6.5\% from 2010 to 2015, resulting in the Chhabdi Khola river basin having $32.17 \%$ agricultural land. With a correlation coefficient of $r=-0.31$ there is a weak negative correlation between the progression of the years and the amount of agricultural area, as can be observed in the graph by the fluctuation in the agricultural area (Fig. 5).

Furthermore, Chhabdi Khola has a few contributing streams named Pamardi Khola, Rantanri Khola, Baraha Khola and Chhaga Khola. As of 2010, Pamardi Khola is a small stream (with a length of approximately $748 \mathrm{~m}$ ) cutting through the agricultural area near small patches of open broadleaved forest, most likely only contributing in the wet seasons. Rantanri Khola has a length of approximately $2085 \mathrm{~m}$ and streams through the area with the

Table 3 Watershed-specific conditions

\begin{tabular}{|c|c|c|c|}
\hline S. N. & Watershed & $\begin{array}{l}\text { Area, stream length, drainage } \\
\text { density }\end{array}$ & Land use type \\
\hline 1 & Chhabdi Khola watershed, Tanahun & $\begin{array}{l}\text { Area: } 28.411 \mathrm{~km}^{2} \\
\text { Stream length: } 19.73 \mathrm{~km} \\
\text { Drainage density: } 0.694\end{array}$ & $\begin{array}{l}57.3 \% \text { broadleaved closed forest; } 8.87 \% \text { broadleaved open } \\
\text { forest; } 33.7 \% \text { agriculture; } 0.14 \% \text { built-up area }\end{array}$ \\
\hline 2 & Guhe Khola watershed, Tanahun & $\begin{array}{l}\text { Area: } 2.275 \mathrm{~km}^{2} \\
\text { Stream length: } 1.68 \mathrm{~km} \\
\text { Drainage density: } 0.738\end{array}$ & $46.48 \%$ broadleaved closed forest and $53.52 \%$ agriculture \\
\hline 3 & Gharmi Khola watershed, Kaski & $\begin{array}{l}\text { Area: } 2958 \mathrm{~km}^{2} \\
\text { Stream length: } 1.72 \mathrm{~km} \\
\text { Drainage density: } 0.581\end{array}$ & $\begin{array}{l}16.48 \% \text { broadleaved closed forest; } 5.44 \% \text { broadleaved open } \\
\text { forest; } 0.30 \% \text { shrub land; } 1.09 \% \text { grassland and } 76.68 \% \\
\text { agriculture }\end{array}$ \\
\hline 4 & Bhoti Khola watershed, Kaski & $\begin{array}{l}\text { Area: } 6.036 \mathrm{~km}^{2} \\
\text { Stream length: } 3.86 \mathrm{~km} \\
\text { Drainage density: } 0.639\end{array}$ & $\begin{array}{l}1.87 \% \text { needle leaved closed forest; } 8.87 \% \text { needle leaved open } \\
\text { forest; } 21.86 \% \text { broadleaved closed forest; } 10.1 \% \text { broad- } \\
\text { leaved open forest; } 0,19 \% \text { shrub land; } 0.31 \% \text { grassland and } \\
56.8 \% \text { agriculture }\end{array}$ \\
\hline
\end{tabular}




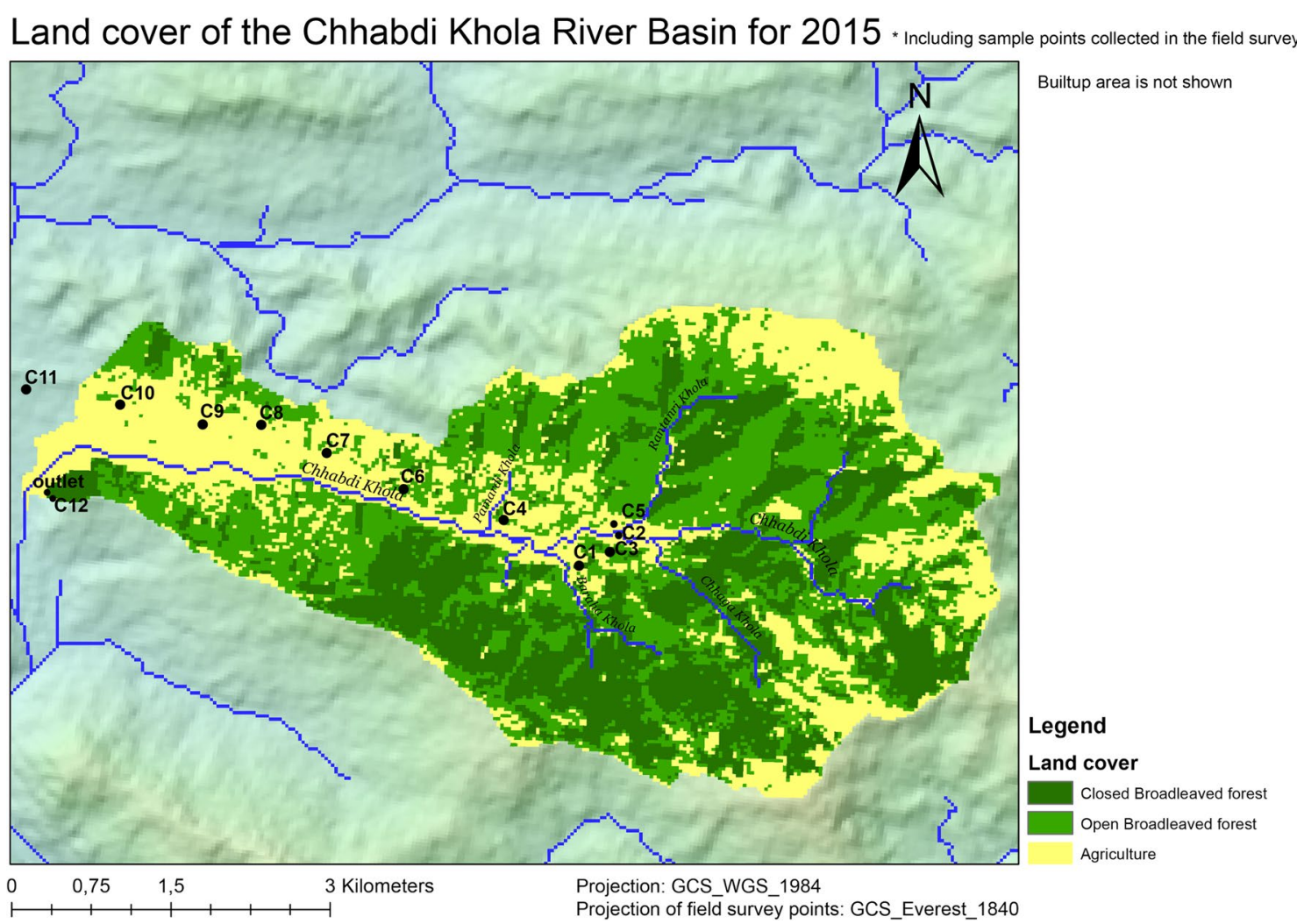

Fig. 3 Land cover mapping for Chhabdi for 2015

mixed open and closed forest, with mostly closed broadleaved forest on its western side. Baraha Khola has a total stream length of about $2258 \mathrm{~m}$ and streams partially trough some agricultural areas and ends in the closed broadleaved forest in the south as well as Chhaga Khola, which has a length of approximately $2058 \mathrm{~m}$.

There seems to be critically little correlation between the progression of years and the share of agricultural area, which creates difficulties to assess whether the agricultural area is actually improving over a longer time period. Nevertheless, the share of the agricultural area is at its lowest in 2015 (compared to the other 5 year intervals), although this is no evidence that the agricultural area will also decrease in the future. Finally, there could also be less erosion as a result of the decrease in bare, agricultural areas (especially at steep slopes). This is also applicable to the other study areas.

\section{Guhe Khola watershed}

Like Chhabdi Khola river basin, the Guhe Khola river basin is also covered for over $60 \%$ by forest, a significant share of which is distributed in small patches of open broadleaved forest throughout the agricultural areas. The closed broadleaved forest is mainly concentrated in the southern part of the river basin. There is generally more open broadleaved forest than closed broadleaved forest. Remarkable is the sizeable difference between the two in 1995 and 2010, with the share of open broadleaved forest being approximately double than the share of closed broadleaved forest $(42.85 \%$ open broadleaved forest vs. $21.88 \%$ closed broadleaved forest in 1995 and $42.19 \%$ open broadleaved forest vs. $19.39 \%$ closed broadleaved forest in 2010) (Fig. 6).

The larger agricultural areas are mainly located in the central and northern parts of the river basin. As can be observed, there is some fluctuation in the share of the agricultural area from 1990 to 2000. After peaking in 2000, the share of agricultural area slips back down until 2015. The share of agricultural is $37.2 \%$ in 1990 vs. $33.33 \%$ in 2015 . With a correlation coefficient of $r=-0.24$ there is a weak negative correlation between the progression of the years and the amount of agricultural area, as can be observed in Fig. 7 by the fluctuation in the agricultural area.

On the basis of the examination of high-resolution satellite imagery and of the field research results, the quality and health of the (open) broadleaved forest could be called into question. A significant amount of open forest seems to be disturbed (at least in 2010-2015), especially the patches 


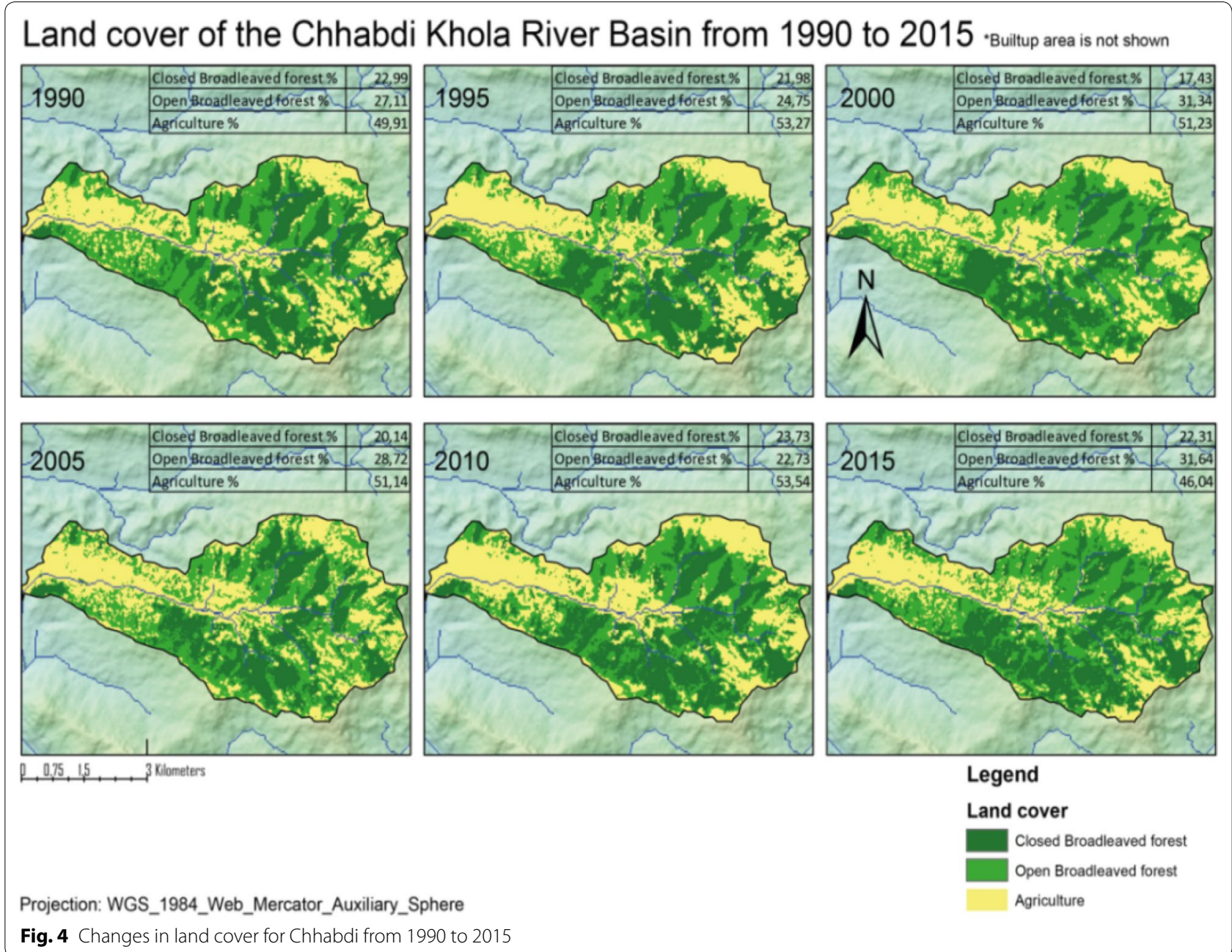

of open broadleaved forest located throughout the agricultural areas. This could also be applicable to the other study areas. Nevertheless, the share of the agricultural area has decreased overall since 1990. This change could have a positive effect on the water balance in the area, not taking into account other factors that could influence the water balance. As for the correlation coefficient, the statements made in the discussion of the results for the Chhabdi Khola river basin also apply to the Guhe Khola river basin.

\section{Bhoti- and Gharmi Khola watersheds}

As can be observed in Fig. 8, the Bhoti- and Gharmi Khola river basins are largely covered by agricultural area (varying from just below 60\% (2015) to 70\% (1990) in the last two- and a half decades). With an exception of the year 2000, the share of the open broadleaved forest is generally higher than the share of the closed broadleaved forest (although particularly with a small margin). Although the share of the closed broadleaved forest is fluctuating (although there is a slight $2.24 \%$ increase from 1990 to 2015), the increase in the open broadleaved

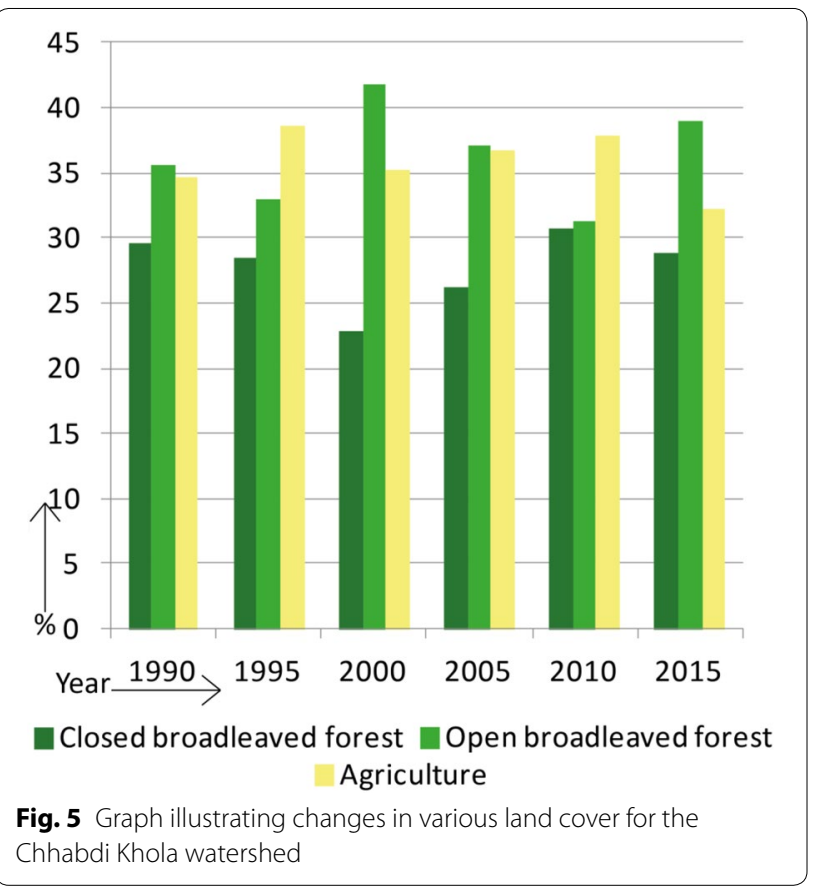



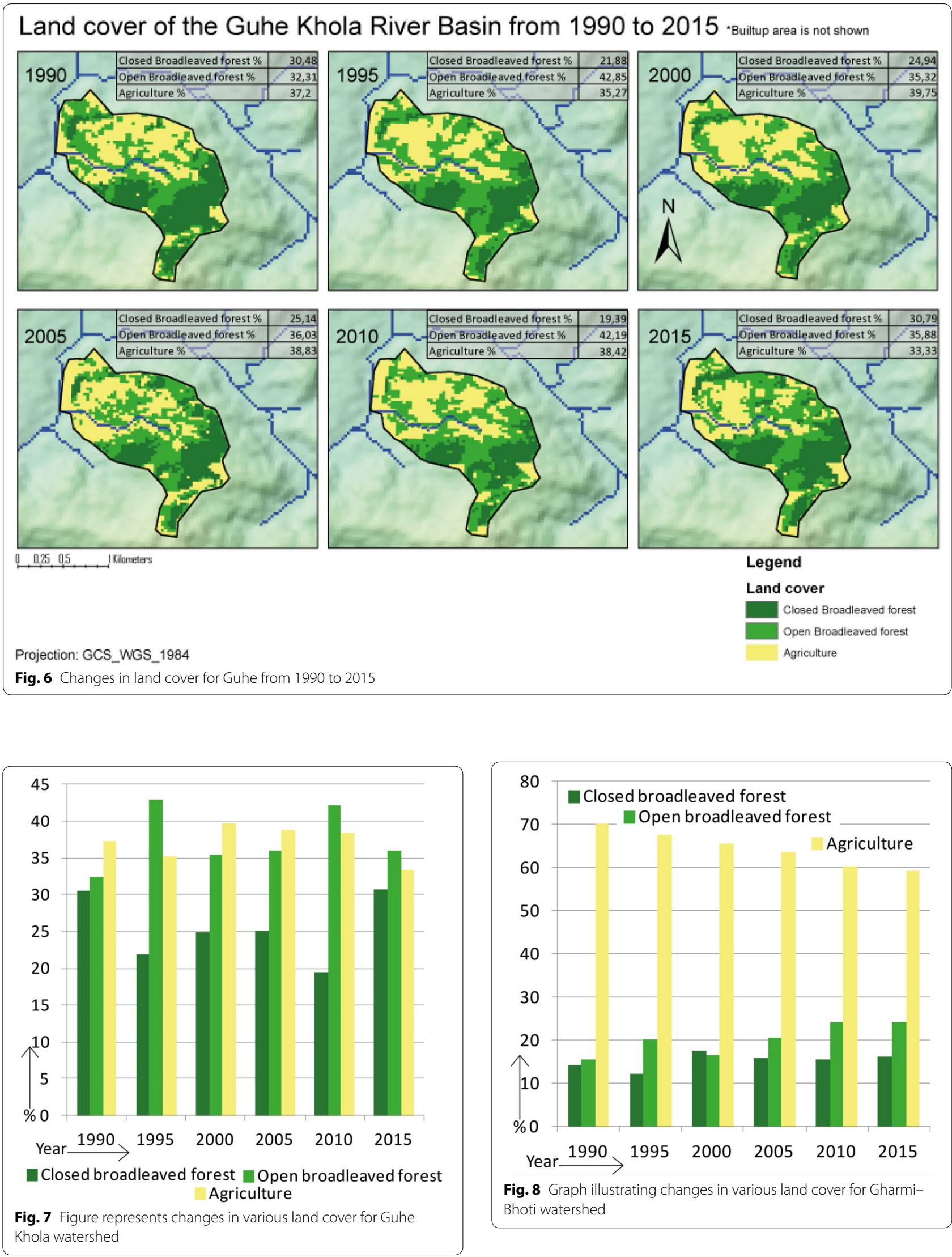

Fig. 8 Graph illustrating changes in various land cover for GharmiBhoti watershed 
forest over the years is more apparent, rising from $15.54 \%$ in 1990 to $24.3 \%$ in 2015.

Finally, an overall downward trend can be observed in the share of the agricultural area. The agricultural area in the Bhoti- and Gharmi Khola river basins seems to be decreasing in each 5-year interval. Overall the share of agricultural area decreased a sizeable $11 \%$, from $70.41 \%$ in 1990 to $59.41 \%$ in 2015 (R. Taylor, January/February 1990). With a correlation coefficient of $r=-0.99$ there is a near exact negative correlation between the progression of the years and the amount of agricultural area, as can be observed in the graph (Fig. 8) by the steady decrease in agricultural area.

With a nearly exact negative correlation between the progression of the years and the share of the agricultural area, a future decrease in the agricultural area could be expected. This could have a positive effect on the water balance, although different influencing factors could also come into play. Changes in land cover for Gharmi-Bhoti from 1990 to 2015 can be observed in Fig. 9.

\section{Accuracy assessment}

During the assessment of the studied watersheds, a total of 38 ground truthing points was covered in order to map the existing scenario of the land use in terms of obtained structures. The primary purpose of the accuracy assessment was to deliver the results based on how well a classification worked under the realistic scenario. Reference data were collected (ground truth) to determine the class types of specific locations. The source of reference data was ground truth with GPS. The plots were carefully selected to account for the low spatial frequency so that homogeneous plot for specific land cover is obtained. The number of reference plot as suggested by Lillesand and Kiefer accounts to be 50 per class as a rule of thumb. However, due to time and resource limitation, only 38 ground truthing points could have been taken on a wholesome basis. The stratified random sampling tool was used to account for representation of the specified land use category (Table 4).

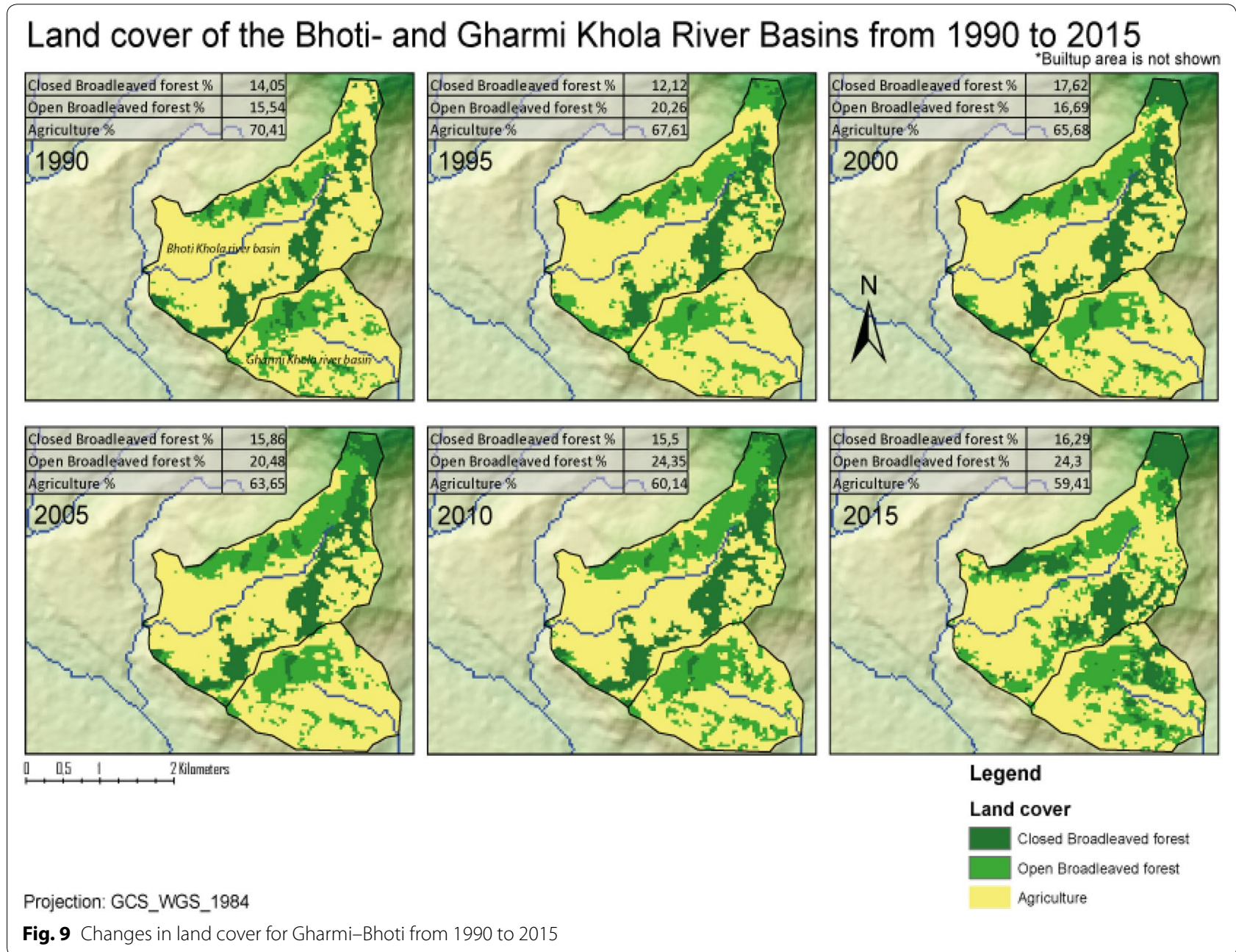


Table 4 Results obtained from classified map and reference source in various watersheds

\begin{tabular}{|c|c|c|c|c|}
\hline $\begin{array}{l}\text { Reference } \\
\text { plot ID }\end{array}$ & $\begin{array}{l}\text { The class determined from a reference } \\
\text { source }\end{array}$ & Reference source & Class claimed on classified map & Agreement status \\
\hline \multicolumn{5}{|l|}{ Chhabdi } \\
\hline C1 & Forest & Closed broadleaved forest & Closed broadleaved forest & Yes \\
\hline C2 & Pasture land & Agriculture & Agriculture & Yes \\
\hline C3 & Orchard farm & Open broadleaved forest & Open broadleaved forest & Yes \\
\hline C4 & Forest floor & Open broadleaved forest & Open broadleaved forest & Yes \\
\hline C5 & Forest land & Closed broadleaved forest & Agriculture & No \\
\hline C6 & $\ldots$ & Open broadleaved forest & Open broadleaved forest & Yes \\
\hline C7 & Fruit farm & Open broadleaved forest & Agriculture & No \\
\hline C8 & Grassland & Open broadleaved forest & Open broadleaved forest & Yes \\
\hline C9 & $\ldots$ & Agriculture & Agriculture & Yes \\
\hline $\mathrm{C} 10$ & Grassland, small shrubs, open public place & Agriculture & Agriculture & Yes \\
\hline C11 & Maize cultivation land & Agriculture & Agriculture & Yes \\
\hline $\mathrm{C} 12$ & Flood plain area, grassland at back & Agriculture & Closed broadleaved forest & No \\
\hline \multicolumn{5}{|l|}{ Guhe } \\
\hline $\mathrm{C} 13$ & Bushy area, shrub land & Agriculture & Agriculture & Yes \\
\hline C14 & Mixed shrub and grassland with local track & Open broadleaved forest & Agriculture & No \\
\hline C15 & Trees & Open forest & Open forest & Yes \\
\hline C16 & Forest & Closed broadleaved forest & Closed broadleaved forest & Yes \\
\hline $\mathrm{C} 17$ & Upland agriculture & Agriculture & Agriculture & Yes \\
\hline $\mathrm{C} 18$ & Kawadi upland with sparse trees & Open broadleaved forest & Open broadleaved forest & Yes \\
\hline C19 & Roadside agriculture land & Agriculture & Agriculture & Yes \\
\hline $\mathrm{C} 20$ & Road edge (forest) & Open broadleaved forest & Open broadleaved forest & Yes \\
\hline \multicolumn{5}{|l|}{ Gharmi } \\
\hline C21 & Agricultural land & Agriculture & Agriculture & Yes \\
\hline $\mathrm{C} 22$ & Fallow land/barren land & Agriculture & Agriculture & Yes \\
\hline $\mathrm{C} 23$ & Open forest land/shrub land & Open broadleaved forest & Open broadleaved forest & Yes \\
\hline $\mathrm{C} 24$ & Upland agricultural land & Agriculture land & Agriculture land & Yes \\
\hline $\mathrm{C} 25$ & Roadside Bari & Agriculture land & Agriculture land & Yes \\
\hline $\mathrm{C} 26$ & Mixed pine forest & Open broadleaved forest & Agriculture land & No \\
\hline C27 & Sparse trees & Open broadleaved forest & Open broadleaved forest & Yes \\
\hline $\mathrm{C} 28$ & Grassland/barren land & Agricultural land & Agriculture land & No \\
\hline C29 & Barren land & Agricultural land & Open broadleaved forest & No \\
\hline C30 & Forest & Open broadleaved forest & Open broadleaved forest & Yes \\
\hline \multicolumn{5}{|l|}{ Bhoti } \\
\hline C31 & Shrubland/forest & Open broadleaved forest & Agriculture & No \\
\hline C32 & Open forest floor & Open broadleaved forest & Agriculture & No \\
\hline C33 & Private Bari & Agriculture & Agriculture & Yes \\
\hline C34 & Fallow land left at the moment & Agriculture & Agriculture & Yes \\
\hline C35 & Barren land & Agricultural land & Agriculture & No \\
\hline C36 & Agriculture land & Agriculture & Agriculture & Yes \\
\hline C37 & Forest floor & Open broadleaved forest & Open broadleaved forest & Yes \\
\hline C38 & Barren land & Agricultural land & Open broadleaved forest & No \\
\hline
\end{tabular}

The analysis of the results illustrating the following kinds of discrepancies is summarised in Table 5 .

The diagonals represent the sites classified correctly according to reference data. Off-diagonal points were misclassified.

$$
\begin{aligned}
\text { Accuracy Total } & =\frac{(2+11 * 16)}{38} \times 100 \\
& =\frac{29}{38} \times 100=76.32 \%
\end{aligned}
$$


Table 5 Summarisation using error matrix

\begin{tabular}{|c|c|c|c|c|}
\hline \multicolumn{5}{|c|}{ Class types determined from a reference source } \\
\hline Plots & Closed broadleaved forest & Open broadleaved forest & Agriculture & Totals \\
\hline \multicolumn{5}{|c|}{ Class types determined from classified map } \\
\hline Closed broadleaved forest & 2 & 0 & 1 & 3 \\
\hline Open broadleaved forest & 0 & 11 & 2 & 13 \\
\hline Agriculture & 1 & 5 & 16 & 22 \\
\hline Total & 3 & 16 & 19 & 38 \\
\hline
\end{tabular}

The problem with total accuracy assessment determined in this case is that it is the summary value representing the average accuracy occurred. This is incapable of shading light upon whether the error is uniformly distributed among the classes. Thus, in order to access the information regarding whether some classes presented are positive or negative, the producer's and user's accuracy also needs to be determined (Subedi and Poudel 2013).

User's accuracy corresponds to the error of commission (inclusion) whereas producer's accuracy corresponds to the error of omission (exclusion) (Table 6).

$$
\begin{aligned}
\text { Accuracy user, closed broadleaved forest } & =\frac{2}{3} \times 100 \\
& =66.67 \% \\
\text { Accuracy user, open broadleaved forest } & =\frac{11}{13} \times 100 \\
& =84.6 \% \\
\text { Accuracy user, agriculture }=\frac{16}{22} \times 100 & =72.7 \%
\end{aligned}
$$

From the perspective of the makers of the classified images, the accuracy of the map is defined by a provided class in the reference plot and by how many points on the classified map are labelled correctly.

$$
\begin{aligned}
\text { Accuracy user, closed broadleaved forest } & =\frac{2}{3} \times 100 \\
& =66.67 \%
\end{aligned}
$$

$$
\text { Accuracyuser, Agriculture }=\frac{16}{19} \times 100=84.2 \%
$$

Kappa statistics reflect the difference between actual agreement and the agreement expected by chance. Kappa of 0.85 means there is $85 \%$ better agreement than by chance alone.

$$
\hat{K}=\frac{\text { Observed Accuracy }- \text { Chance Agreement }}{1-\text { Chance Agreement }}
$$

The kappa statistics calculation in terms of calculation of chance agreement comes out to be 0.88 . The chance agreement has been determined on the basis of chance agreement (Sum of the product of row and column totals for each class). Kappa of 0.88 means there is $88 \%$ better agreement on the obtained value than by chance alone.

\section{Classification of images using sentinel data}

The classification was also made on the basis of freely available data from Sentinel satellite. The result obtained from the analysis is depicted in Fig. 10.

As can be observed from Fig. 10, the land cover clas-

\begin{tabular}{|c|c|c|c|c|c|c|}
\hline \multirow{2}{*}{$\begin{array}{l}\text { Class types determined } \\
\text { from classified map }\end{array}$} & \multicolumn{6}{|c|}{ Class types determined from a reference source } \\
\hline & Plots & $\begin{array}{l}\text { Closed broadleaved } \\
\text { forest }\end{array}$ & $\begin{array}{l}\text { Open broadleaved } \\
\text { forest }\end{array}$ & Agriculture & Totals & User's accuracy \\
\hline & Closed broadleaved forest & 2 & 0 & 1 & 3 & 66.67 \\
\hline & Open broadleaved forest & 0 & 11 & 2 & 13 & 84.6 \\
\hline & Agriculture & 1 & 5 & 16 & 22 & 72.7 \\
\hline & Total & 3 & 16 & 19 & 38 & \\
\hline & Producer's Accuracy & 66.67 & 68.75 & 84.2 & & 76.32 \\
\hline
\end{tabular}
sification for Chhabdi Khola watershed shows $41.36 \%$ coverage by closed broad leaved forest, $11.43 \%$ by open broadleaved forest, $35.46 \%$ by agricultural land, $9.17 \%$ by built up areas, $2.57 \%$ by road infrastructure..

As for Guhe Khola watershed, the percentage coverage was $34.32,4.825,21.14,33.25$ and $6.46 \%$ respectively of closed broadleaved forest, open broadleaved forest,

Table 6 Table illustrating calculation of user's accuracy and producer's accuracy 

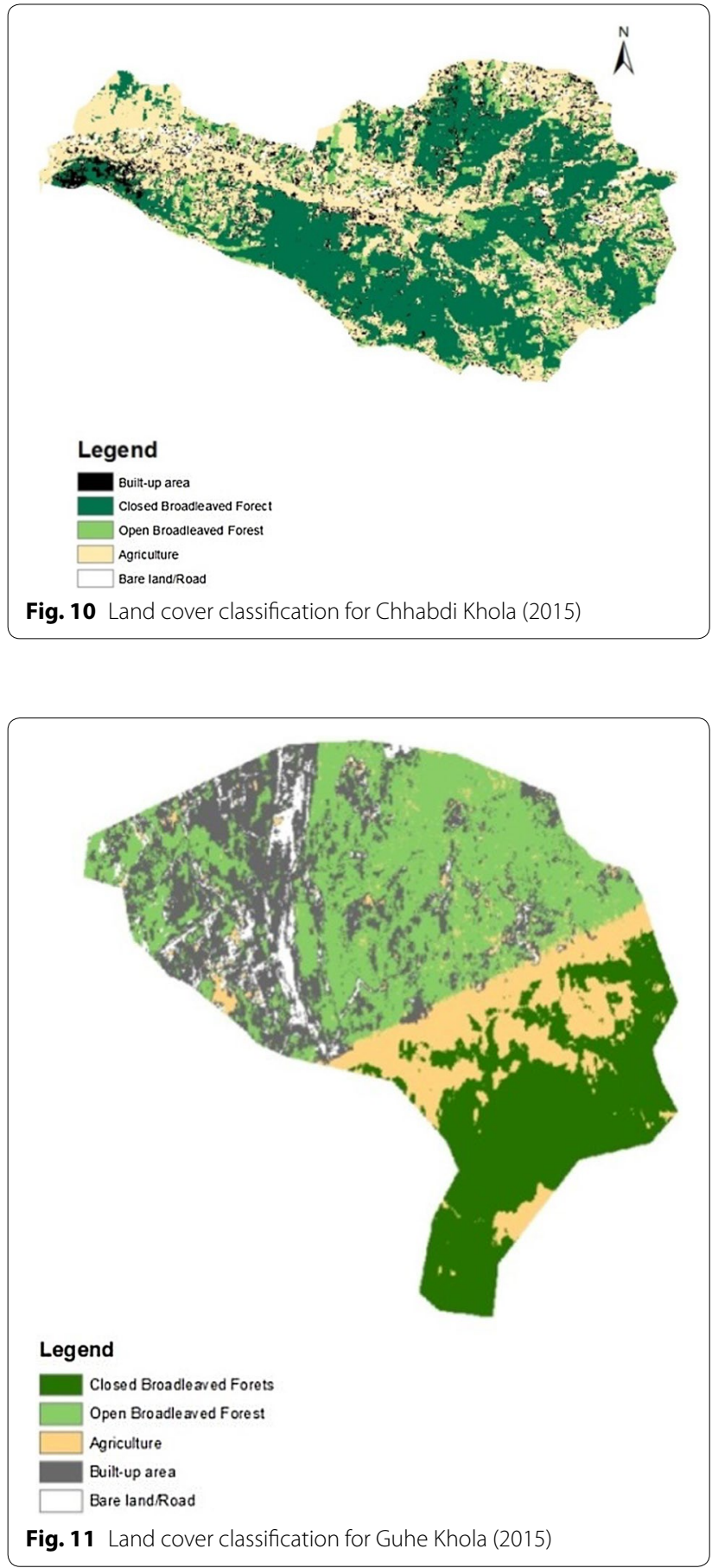

agricultural land, built up areas and road/barren land (Fig. 11).

Similarly, the land cover percentage was 19.31, 17.86, $16.81,39.62$ and $6.38 \%$ respectively for the closed broadleaved forest, open broadleaved forest, agricultural land, built up the area and road/barren area for Gharmi-Bhoti Khola watershed (Fig. 12). Land-cover mapping classes for Kaski-Tanahun can be observed in Fig. 13 (Table 7).

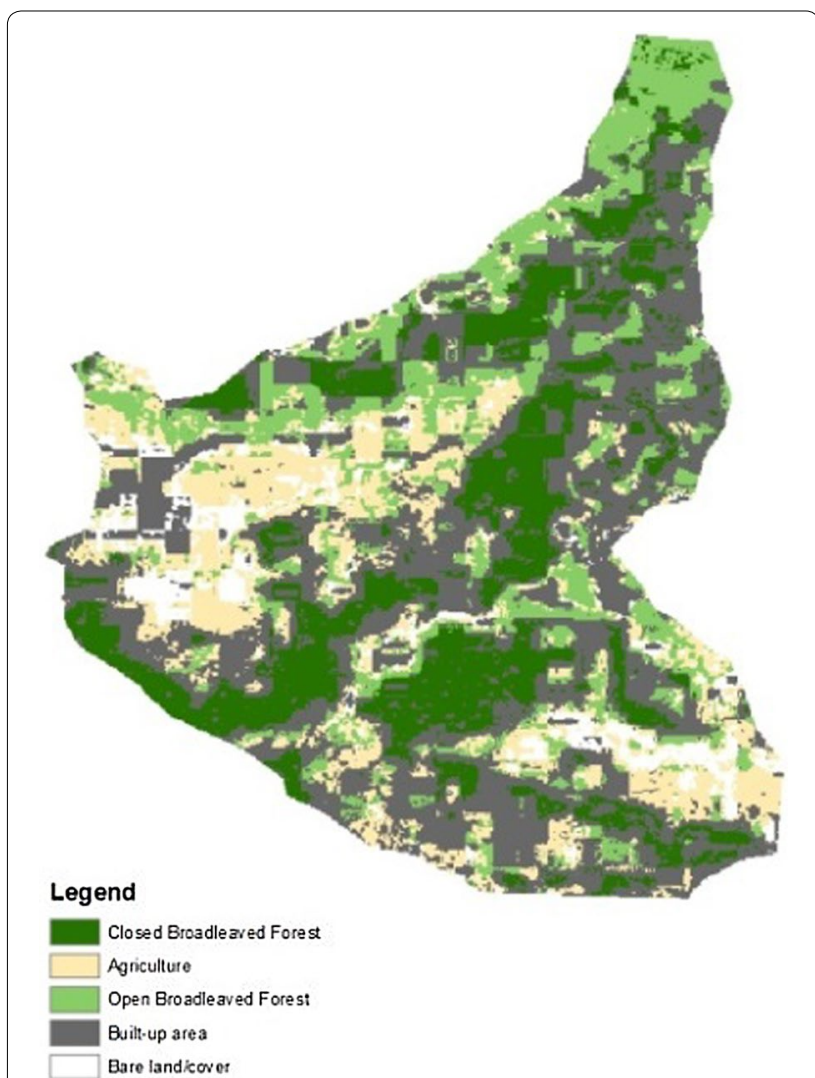

Fig. 12 Land cover classification for Gharmi-Bhoti Khola watershed (2015)

\section{Temperature and rainfall changes during 1985-2014 year} ( 30 years)

Temperature changes during 1985-2014 period

The Figs. 14, 15 and 16 illustrate the mean temperature for Pokhara airport, Khairinitar station and Damauli station from 1985 to 2014. The Fig. 14 illustrates the maximum, minimum and mean temperature for Pokhara airport from 1985 to 2014. Temperature, as depicted by the station, provided the increasing trend. The maximum temperature was found to reach the peak at 2009 with $28.008{ }^{\circ} \mathrm{C}$ and lowest in 1997 with $25.742{ }^{\circ} \mathrm{C}$, which was statistically significant. Minimum temperature also exhibited an increased trend with the highest value of $17.100{ }^{\circ} \mathrm{C}$ in 2008 and the lowest value of $14.350{ }^{\circ} \mathrm{C}$ in 2014 but this fact was not statistically significant. The mean temperature was found to be highest in 2008 with the temperature of $22.154{ }^{\circ} \mathrm{C}$ and lowest in 1997 with $20.233^{\circ} \mathrm{C}$. The trend for mean temperature was seemed to be increasing which was also statistically significant.

Looking at the 30 years' average of maximum temperature in the Khairinitar station (Fig. 15), the slope was decreasing with the highest value of $30.725{ }^{\circ} \mathrm{C}$ in 2005 and lowest with $27.683{ }^{\circ} \mathrm{C}$ in 1996 which was also 


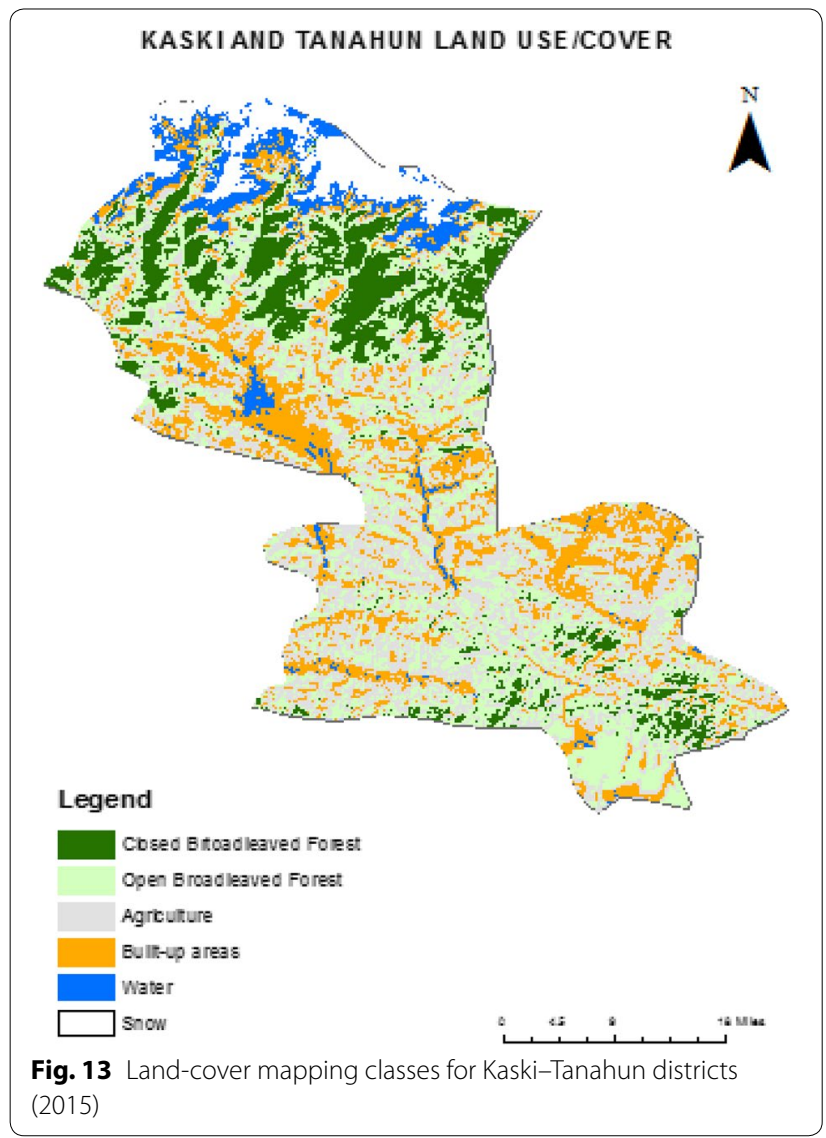

Table 7 Land-cover mapping classes for Kaski-Tanahun districts (2015)

\begin{tabular}{llc}
\hline S. N. & Land use/cover type & Percentage covered (\%) \\
\hline 1 & Closed broadleaved forest & 13.67 \\
2 & Opened broadleaved forest & 27.15 \\
3 & Agriculture & 29.80 \\
4 & Built-up areas & 18.59 \\
5 & Water & 5.62 \\
6 & Snow & 5.17 \\
Total & & 100.00 \\
\hline
\end{tabular}

statistically non-significant. But on the other hand, minimum temperature exhibited an increasing trend in the interval of 30 years. The highest value was found to be in 1997 with $17.816{ }^{\circ} \mathrm{C}$ and the lowest value was $15.400{ }^{\circ} \mathrm{C}$ in 1991, and the trend was statistically significant. The mean temperature in the same station also depicted that the slope was increasing although there was a great fluctuation in between 30 years with highest temperature in $2007\left(23.729{ }^{\circ} \mathrm{C}\right)$ and the lowest temperature in $1991\left(22.341{ }^{\circ} \mathrm{C}\right)$ with statistically significant value with respect to $\mathrm{R} 2$.
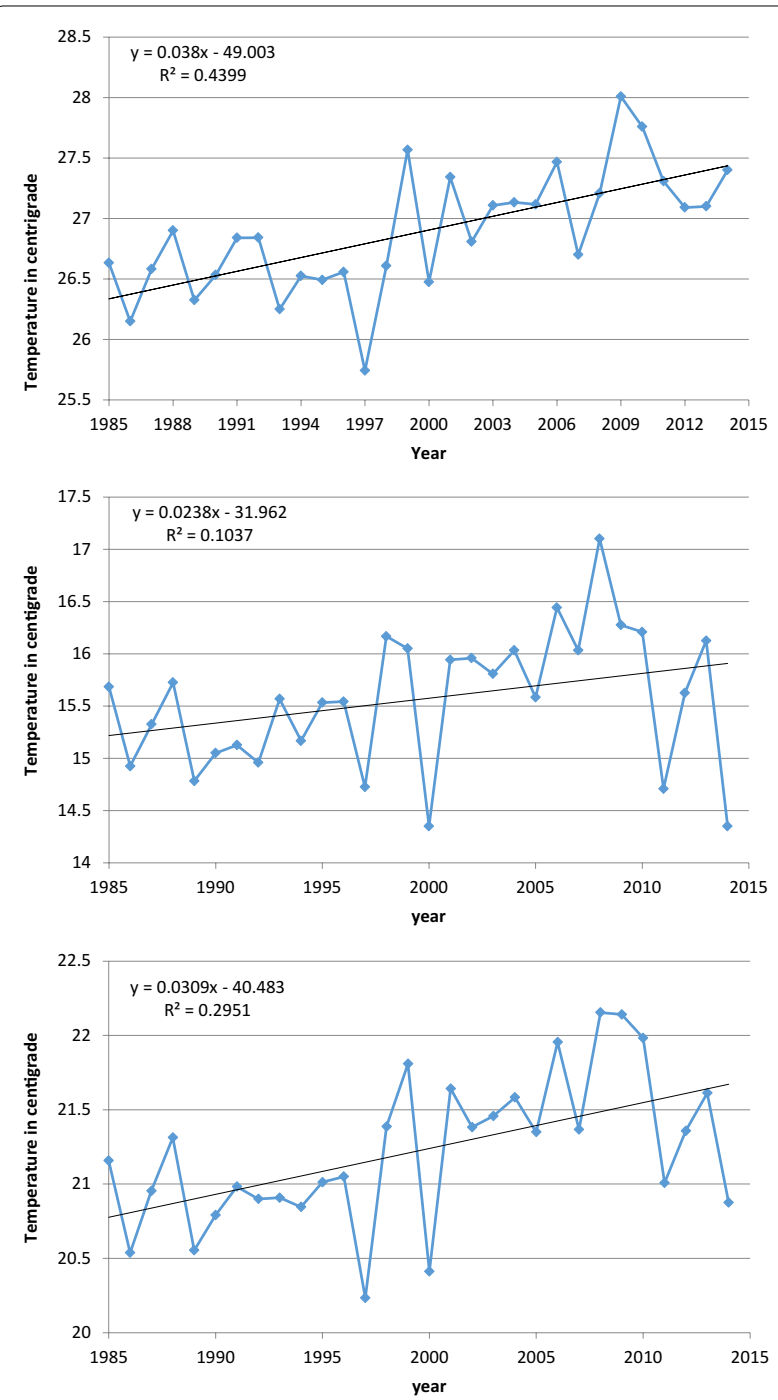

Fig. 1430 years' maximum, minimum and mean temperature trend for Pokhara station

The data for the temperature in the case of Damauli station were available only from 2004 to 2014. An increasing trend of temperature was observed in the case of maximum temperature with statistical significance with respect to the value of $\mathrm{R} 2$. The temperature reached the peak in $2014\left(31.891^{\circ} \mathrm{C}\right)$ and was found to reach the minimum in $2007\left(29.275^{\circ} \mathrm{C}\right)$. The minimum and mean temperature, both decreased by $0.158{ }^{\circ} \mathrm{C}$ and $0.012{ }^{\circ} \mathrm{C}$ respectively. The minimum temperature was high in 2004 with the temperature of $2.487^{\circ} \mathrm{C}$ and low in 2008 with $15.442{ }^{\circ} \mathrm{C}$ whereas mean temperature was found to be highest with the value of $25.337{ }^{\circ} \mathrm{C}$ in 2004 and lowest with $22.583{ }^{\circ} \mathrm{C}$ in 2008 . The trend in minimum temperature was statistically significant, whereas, in the case of mean temperature, the data were not statistically indicative. 

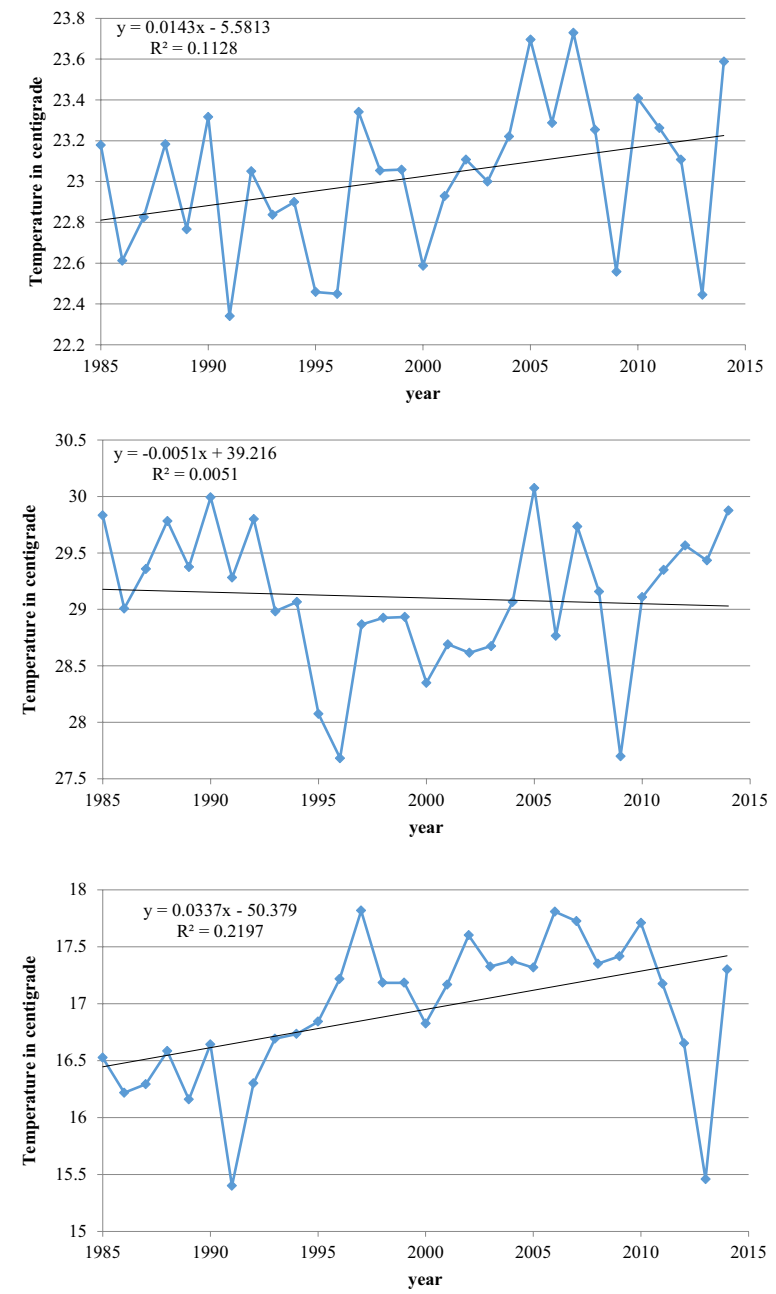

Fig. 1530 years' maximum, minimum and mean temperature trend for Khairinitar station

\section{Rainfall changes during 1985-2014 period}

As represented by all four stations in the study area (Fig. 17), the thirty-year total annual rainfall provides decreasing trend. On the basis of the coefficient of determination (R2), the decrease in rainfall was not statistically significant.

The highest rainfall (in $\mathrm{mm}$ ) that was received at each station (Lamachaur, Pokhara airport, Damauli and Khairinitar) were $5365.2 \mathrm{~mm}$ in 2007,4879 in $1998,2254.1$ in 1999 and 3057.6 in 2002) respectively. On the other hand, the lowest rainfall (in $\mathrm{mm}$ ) that each of the stations received are $3114.22001,2967.1$ in 2002, 1171.2 in 1992, 1684.9 in 2009.

\section{Assessment of regional changes for water availability}

The average discharge measured during the study period as measured with the help of Float method is $0.32 \mathrm{~m}^{3} / \mathrm{s}$ for Chhabdi Khola, $0.07 \mathrm{~m}^{3} / \mathrm{s}$ for Guhe Khola, $0.04 \mathrm{~m}^{3} / \mathrm{s}$ for Gharmi Khola and $0.13 \mathrm{~m}^{3} / \mathrm{s}$ for Bhoti Khola. The relative moisture values measured in the field during the study period are $18.3 \%$ for Chhabdi Khola, $17.5 \%$ for Guhe Khola, 31.3\% for Gharmi Khola and 20.9\% for Bhoti Khola (Tables 8, 9).

Table 10 highlights the information regarding local meteorological conditions collected during the study.

As per the people perception in the study area, the role of recent climate change is more pronounced. During the last 30 years, the amount of precipitation has decreased, while the temperature pattern illustrates an increasing trend. This can cause higher evaporation and lack of sufficient moisture in the soil during critically hot seasons. That is why a dense vegetation cover is so essential.

The impact of land cover changes on the landscape features of watersheds greatly affects channel flows (Gautam et al. 2003). Urbanisation increases the imperviousness and reduces infiltration of precipitation (El Alfy 2016). Vegetation removal causes reduction of rainfall interception and, storage and, in arid/semiarid regions, the creation of physical crusts (Tang 2016). The forest cover, among other factors, affects the storage capacity of a watershed and is instrumental in sustaining the flow of water in rivers at times when precipitation is lacking or is just sufficient to cover evaporation. The computations based on actual gauzing illustrates that while the cultivated and forested watersheds yield almost the same amount, the cultivated watershed exudes the water faster during the first months, and therefore sooner becomes exhausted (Kerr 2002).

From the year 1990 to 2015, Chhabdi Khola and Guhe Khola watersheds displays an increase in overall forest cover and decrease in the percentage of the agricultural lands. This fact means that it will create an appropriate water storage by increasing percolation of the soil during the rainfall and will provide proper water availability (Gautam et al. 2003). Land use pattern along with changing climate play a substantial role in determining water supply ecosystem services in a landscape (Dale 1997). Typically, with the change in forest cover, contribute equally to impact such ecosystem services. In the existing scenario of haphazard and unorganised land use practice, optimum water availability is at stake, thus disturbing the ecosystem balance. There is a need for a better understanding of the interactions between forests/trees and water, for awareness raising and capacity building in forest hydrology, and for embedding this knowledge and the research findings into policies (Calder et al. 2007).

\section{Conclusion and recommendation}

Presented study demonstrates that the land cover practice is changing in the areas of study, although there is no a clear trend of change. In most of the cases, the 

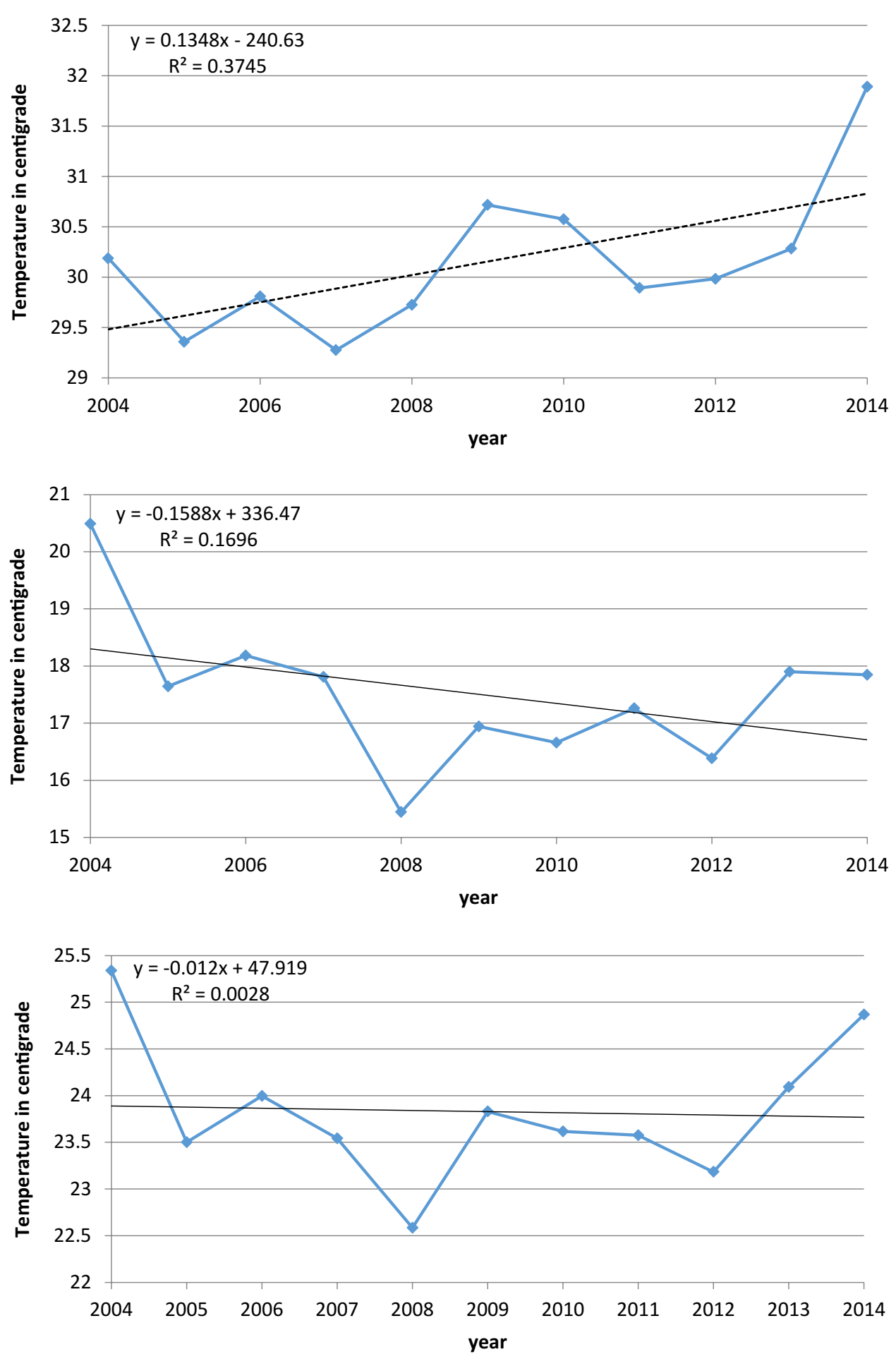

Fig. 1611 years' maximum, minimum and mean temperature trend for Damauli station

share of the open broadleaved forest is higher. In the case of the closed broadleaved forest, there has been the improvement in the recent years. The trend is initially decreasing with the afterward increase. The causes could be particularly attributed to the amelioration in community, forestry and management practices. In the case 

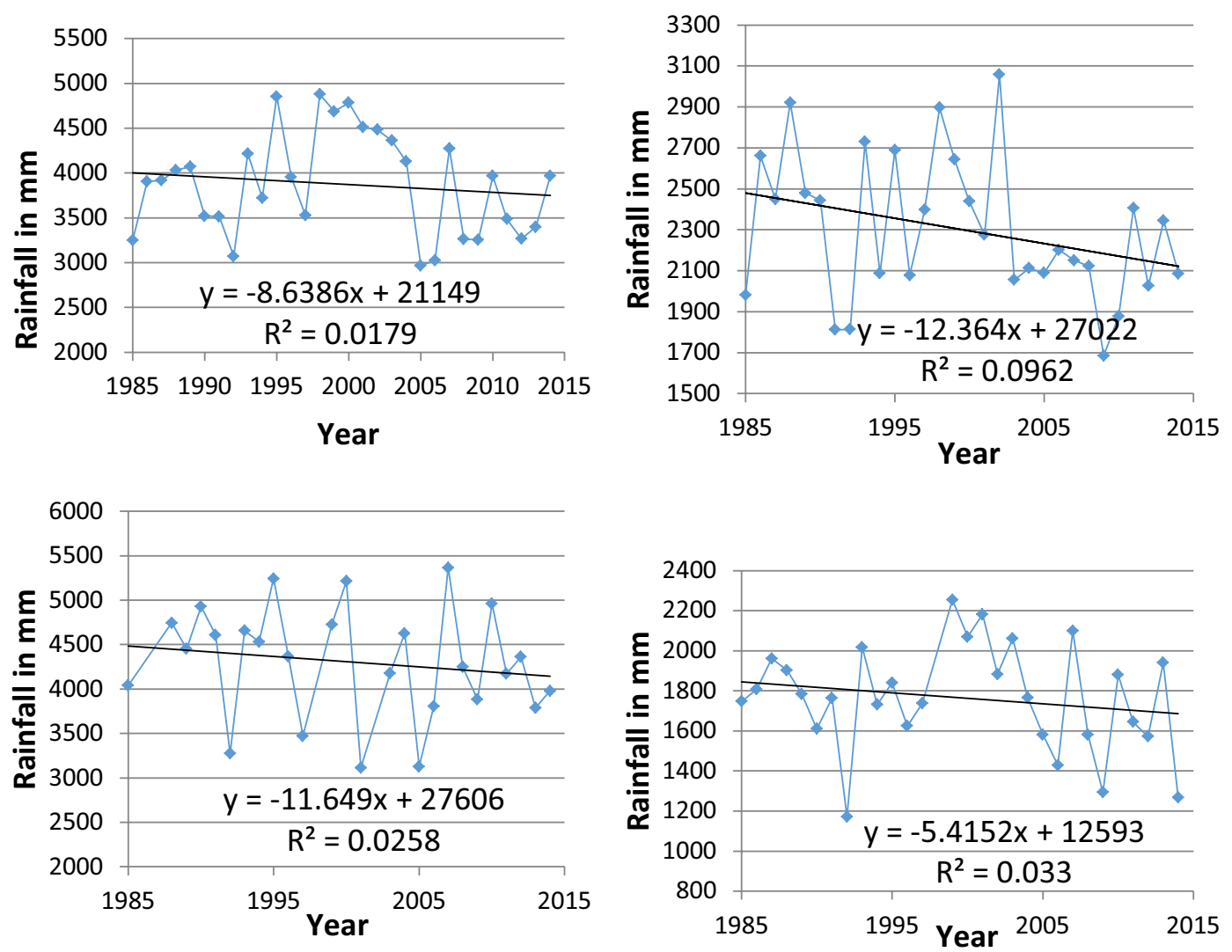

Fig. 1730 years of total annual rainfall (1985-2014) trend in the study area (Pokhara airport, Khairinitar, Lamachaur, and Damauli)

Table 8 Surface flow velocity, average cross section of river and estimated discharge in the river

\begin{tabular}{|c|c|c|c|c|c|c|c|}
\hline \multirow{2}{*}{$\begin{array}{l}\text { River } \\
\text { Chhabdi Khola }\end{array}$} & \multirow{2}{*}{$\begin{array}{l}\text { Distance }(\mathrm{m}) \\
9.2\end{array}$} & \multicolumn{2}{|c|}{ Time (s) (T) } & \multirow[t]{2}{*}{$\begin{array}{l}\text { Surface } \\
\text { velocity }\end{array}$} & \multirow[t]{2}{*}{$\begin{array}{l}\text { Cross } \\
\text { section area }\end{array}$} & \multirow{2}{*}{$\begin{array}{l}\text { Actual velocity } \\
\mathbf{( 0 . 8 5 *} \text { surface velocity }\end{array}$} & \multirow[t]{2}{*}{ Discharge $(\mathrm{Q})=\mathrm{AV}$} \\
\hline & & & $\begin{array}{l}\text { Average time } \\
\text { (s) }\end{array}$ & & & & \\
\hline & & 12.8 & 11.91 & 0.77 & 0.4905 & 0.66 & 0.32 \\
\hline & & 10.99 & & & & & \\
\hline & & 11.94 & & & & & \\
\hline \multirow[t]{3}{*}{ Guhe Khola } & 7 & 9.12 & 8.93 & 0.78 & 0.105 & 0.67 & 0.07 \\
\hline & & 8.97 & & & & & \\
\hline & & 8.7 & & & & & \\
\hline \multirow[t]{4}{*}{ Gharmi Khola } & 6 & 4.53 & 4.24 & 1.42 & 0.03 & 1.20 & 0.04 \\
\hline & & 4.14 & & & & & \\
\hline & & 4.12 & & & & & \\
\hline & & 4.17 & & & & & \\
\hline \multirow[t]{3}{*}{ Bhoti Khola } & 2.47 & 2.32 & 2.52 & 0.98 & 0.16 & 0.83 & 0.13 \\
\hline & & 2.88 & & & & & \\
\hline & & 2.37 & & & & & \\
\hline
\end{tabular}


Table 9 Relative moisture data

\begin{tabular}{ll}
\hline Watershed & $\begin{array}{l}\text { Relative soil } \\
\text { moisture \% }\end{array}$ \\
\hline Chhabdi Khola & 18.3 \\
Guhe Khola & 17.5 \\
Gharmi Khola & 31.3 \\
Bhoti Khola & 20.9 \\
\hline
\end{tabular}

of Gharmi-Bhoti Khola watershed, the agricultural land proportion is higher, which also illustrates a decreasing trend. Overall, despite changing climate, increase of temperature and decrease of rainfall pattern, the vegetation cover presents a rising tendency what may have positive effects on the water availability in the Kaski and Tanahun regions.

The research tried to connect knowledge, peoples' perception as well as various sectors and actions concerned, in order to understand the implications related to land use management and possibly to improve water availability for society. The research includes integrated land use changes, vegetation cover, climatic trends and potential function of this knowledge for local people, farmers, regional and national governing agencies. Though the results extracted from this study are applicable to the smaller domain for implementation, the study, however, could be easily replicated in other areas of interest for understanding site specific situation.

The present assessment of regional changes in Kaski and Tanahun regions recommends necessary steps at local farmers, governmental and non-governmental organisations. The local farmers should accentuate management of community forest so, that the sparse distribution of vegetation could be minimised. Since practice for nontimber forest species is not in the trend in the research area, such species together with low water demand crops should be considered. Farmers can change cropping season and crop type as per seasonal water availability. The local authority together with farmer's groups should develop water storage ponds and irrigation canal for supplying water for agricultural needs. The governmental and non-governmental organisations should stress environmentally friendly local governance focused on conserving

Table 10 Land use type, air temperature $\left({ }^{\circ} \mathrm{C}\right)$, relative humidity $(\%)$ and soil temperature $\left({ }^{\circ} \mathrm{C}\right)$ in the study area

\begin{tabular}{|c|c|c|c|c|c|c|c|c|c|}
\hline \multirow{2}{*}{$\begin{array}{l}\text { Name } \\
\text { of place }\end{array}$} & \multirow[t]{2}{*}{ Location } & \multicolumn{3}{|l|}{ Locations } & \multirow{2}{*}{$\begin{array}{l}\text { Types } \\
\text { of land use }\end{array}$} & \multirow{2}{*}{$\begin{array}{l}\text { Time of } \\
\text { the day }\end{array}$} & \multirow{2}{*}{$\begin{array}{l}\text { Air tempera- } \\
\text { ture }\left({ }^{\circ} \mathrm{C}\right)\end{array}$} & \multirow{2}{*}{$\begin{array}{l}\text { Relative } \\
\text { humidity (\%) }\end{array}$} & \multirow{2}{*}{$\begin{array}{l}\text { Soil tem- } \\
\text { perature }\left({ }^{\circ} \mathrm{C}\right)\end{array}$} \\
\hline & & Latitude & Longitude & Altitude $(\mathrm{ft})$ & & & & & \\
\hline $\begin{array}{c}\text { Chhabdi } \\
\text { outlet }\end{array}$ & $\begin{array}{l}\text { Chabdi } \\
\text { watershed }\end{array}$ & $27^{\circ} 57^{\prime} 56^{\prime \prime}$ & $84^{\circ} 16^{\prime} 35^{\prime \prime}$ & 820 & Flood basin & 4:30 P.M. & 22 & 76 & 19 \\
\hline $\begin{array}{l}\text { Chhabdi } \\
\text { Mandir }\end{array}$ & & $27^{\circ} 57^{\prime} 37^{\prime \prime}$ & $84^{\circ} 19^{\prime} 06^{\prime \prime}$ & 1260 & Forest land & 9:20 P.M. & 18 & 82 & 17 \\
\hline Belghari & & $27^{\circ} 57^{\prime} 49^{\prime \prime}$ & $84^{\circ} 18^{\prime} 47^{\prime \prime}$ & 1140 & Shrub land & 11:15 P.M. & 19 & 63 & 17.5 \\
\hline $\begin{array}{c}\text { Bhadkhala, } \\
\text { Chhabdi }\end{array}$ & & $27^{\circ} 58^{\prime} 08^{\prime \prime}$ & $84^{\circ} 18^{\prime} 03^{\prime \prime}$ & 1095 & Bare land & 12:15 P.M. & 22 & 64 & 21 \\
\hline $\begin{array}{l}\text { Moriyatar, } \\
\text { Chhabdi }\end{array}$ & & $27^{\circ} 58^{\prime} 18^{\prime \prime}$ & $84^{\circ} 17^{\prime} 41^{\prime \prime}$ & 1138 & Grassland & 1:10 P.M. & 21 & 68 & 19 \\
\hline Damauli & & $27^{\circ} 58^{\prime} 29^{\prime \prime}$ & $84^{\circ} 16^{\prime} 29^{\prime \prime}$ & 1092 & Private land & 2:40 P.M. & 22 & 55 & 21.5 \\
\hline Kawadi & $\begin{array}{l}\text { Guhe } \\
\text { watershed }\end{array}$ & $28^{\circ} 00^{\prime} 54^{\prime \prime}$ & $84^{\circ} 06^{\prime} 09^{\prime \prime}$ & 1626 & $\begin{array}{l}\text { Cultivated } \\
\text { land }\end{array}$ & 9:50 A.M. & 15.5 & 78 & 16 \\
\hline Kawadi & & $28^{\circ} 00^{\prime} 37^{\prime \prime}$ & $84^{\circ} 06^{\prime} 15^{\prime \prime}$ & 1665 & Open forest & 10:10 A.M. & 15 & 72 & 17 \\
\hline $\begin{array}{l}\text { Bhulbhule } \\
\text { (nearby } \\
\text { Guhe } \\
\text { outlet) }\end{array}$ & & $28^{\circ} 00^{\prime} 53^{\prime \prime}$ & $84^{\circ} 05^{\prime} 55^{\prime \prime}$ & 1496 & Grassland & 10:45 A.M. & 16 & 84 & 17 \\
\hline $\begin{array}{l}\text { Nearby } \\
\text { Gharmi } \\
\text { Khola outlet }\end{array}$ & $\begin{array}{l}\text { Gharmi } \\
\text { watershed }\end{array}$ & $28^{\circ} 16^{\prime} 32^{\prime \prime}$ & $83^{\circ} 59^{\prime} 05^{\prime \prime}$ & 3094 & $\begin{array}{l}\text { Cultivated } \\
\text { land } \\
\text { (paddy) }\end{array}$ & 9:15 A.M. & 16 & 64 & 13 \\
\hline Aarmala & & $28^{\circ} 16^{\prime} 39^{\prime \prime}$ & $83^{\circ} 58^{\prime} 51^{\prime \prime}$ & 3205 & Private land & 9:45 A.M. & 20 & 54 & 14 \\
\hline Gharmi & & $28^{\circ} 16^{\prime} 35^{\prime \prime}$ & $83^{\circ} 58^{\prime} 52^{\prime \prime}$ & 3130 & Barren land & 10:00 A.M. & 19 & 63 & 13 \\
\hline $\begin{array}{l}\text { Nearby Bhoti } \\
\text { outlets }\end{array}$ & $\begin{array}{l}\text { Bhoti } \\
\text { watershed }\end{array}$ & $28^{\circ} 16^{\prime} 30^{\prime \prime}$ & $83^{\circ} 59^{\prime} 04^{\prime \prime}$ & 3178 & $\begin{array}{c}\text { Nigalo bam- } \\
\text { boo forest }\end{array}$ & 2:35 P.M. & 18 & 56 & 15 \\
\hline Besichowk & & $28^{\circ} 17^{\prime} 11^{\prime \prime}$ & $83^{\circ} 57^{\prime} 12^{\prime \prime}$ & 3657 & $\begin{array}{l}\text { Cultivated } \\
\text { land }\end{array}$ & 3:20 P.M. & 16 & 60 & 13 \\
\hline Besichowk & & $28^{\circ} 17^{\prime} 13^{\prime \prime}$ & $83^{\circ} 57^{\prime} 15^{\prime \prime}$ & 3655 & Barren land & 3:35 P.M. & 15 & 64 & 13 \\
\hline
\end{tabular}


water resources in the area. Climate resilient development should be prioritised since climate change influence has been observed in the form of increasing temperature and decreasing precipitation in the study area.

\section{Authors' contributions}

All authors have contributed to the work as per research requirement. All authors read and approved the final manuscript.

\section{Author details}

${ }^{1}$ Health and Environmental Management Society (HEMS), Basundhara, Kathmandu, Nepal. ${ }^{2}$ World Wildlife Fund (WWF), Baluwatar, Kathmandu, Nepal.

${ }^{3}$ UIZ Umwelt und Informationstechnologie Zentrum GmbH, Neue Grünstraße 38, 10179 Berlin, Germany.

\section{Acknowledgements}

The presented work is part of a research project entitled "Assessment of Land Cover and its Contribution to Runoff Response in Watershed to aid land use planning for sustainable landscape: A Pilot Research Study in Small Watersheds of Tanahun and Kaski Districts, Nepal". The research was financially supported by USAID funded Hariyo Ban Program through World Wildlife Fund (WWF), Kathmandu, Nepal (grant number: AID-367-A-11-00003) and UIZ Umwelt und Informationstechnologie Zentrum GmbH, Berlin, Germany.

\section{Competing interests}

The authors declare that they have no competing interests.

\section{Availability of data and materials}

The data used in the presented work has been purchased or, has been used freely available. All the data used in the present work are stored at our institution. A survey conducted in the work has been approved by the audience.

\section{Consent for publication}

The author hereby consents to publication of the work in the Environmental Systems Research. The author warrants that the work has not been published before in any form except in-house project presentation, that the WORK is not being concurrently submitted to and is not under consideration by another publisher, that the persons listed.

The author also warrants that the work does not libel anyone, infringe anyone's copyright, or otherwise violate anyone's statutory or common law rights.

\section{Ethics approval and consent to participate}

The presented work is part of the research project entitled "Assessment of Land Cover and its Contribution to Runoff Response in Watershed to aid land use planning for sustainable landscape: A Pilot Research Study in Small Watersheds of Tanahun and Kaski Districts, Nepal". There is no any ethical conflict. Authors on behalf of an associated organisation fully authorise to publish research.

\section{Funding}

The research was financially supported by World Wildlife Fund (WWF), Kathmandu, Nepal (grant number: AID-367-A-11-00003) and technologically supported by UIZ Umwelt und Informationstechnologie Zentrum GmbH, Berlin, Germany.

\section{Publisher's Note}

Springer Nature remains neutral with regard to jurisdictional claims in published maps and institutional affiliations.

Received: 11 January 2017 Accepted: 11 July 2017

Published online: 14 August 2017

\section{References}

Atkinson S, Woods R et al (2002) Climate and landscape controls on water balance model complexity over changing timescales. Water Resour Res 38(12):1314
Calder I, Hofer T et al (2007) Towards a new understanding of forests and water. Unasylva 58(229):3-10

Dale VH (1997) The relationship between land-use change and climate change. Ecol Appl 7(3):753-769

Dolisca F, McDaniel JM et al (2007) Farmers' perceptions towards forests: a case study from Haiti. For Policy Econ 9(6):704-712

El Alfy M (2016) Assessing the impact of arid area urbanization on flash floods using GIS, remote sensing, and HEC-HMS rainfall-runoff modeling. Hydrol Res 47:1142-1160

Foody GM (2002) Status of land cover classification accuracy assessment. Remote Sens Environ 80(1):185-201

Gautam AP, Webb EL et al (2003) Land use dynamics and landscape change pattern in a mountain watershed in Nepal. Agr Ecosyst Environ 99(1):83-96

Ghimire CP, Bruijnzeel LA et al (2014) The effects of sustained forest use on hillslope soil hydraulic conductivity in the Middle Mountains of Central Nepal. Ecohydrology 7(2):478-495

Keninger ZA (2012) Assessing land cover map accuracy and performance of hydrological models for small stream catchments using GIS. MSc, lola State University, lola

Kerr J (2002) Sharing the benefits of watershed management in Sukhomajri, India. Selling forest environmental services, Market-based mechanisms for conservation and development, pp 327-343

Li D, Pan M et al (2013) Vegetation control on water and energy balance within the Budyko framework. Water Resour Res 49(2):969-976

Merz J, Dangol PM et al (2006) Rainfall-runoff events in a middle mountain catchment of Nepal. J Hydrol 331(3):446-458

Pielke R, Adegoke J et al (2007) An overview of regional land-use and landcover impacts on rainfall. Tellus B 59(3):587-601

Schmidt MW, Torn MS et al (2011) Persistence of soil organic matter as an ecosystem property. Nature 478(7367):49-56

Schmithüsen F, Wild-Eck S (2000) Uses and perceptions of forests by people living in urban areas - findings from selected empirical studies. Forstwissenschaftliches Centralblatt vereinigt mit Tharandter forstliches Jahrbuch 119(1):395-408

Shrestha AB, Aryal R (2011) Climate change in Nepal and its impact on Himalayan glaciers. Reg Environ Change 11(1):65-77

Singh P, Thakur JK et al (2011) Assessment of land use/land cover using Geospatial Techniques in a semi arid region of Madhya Pradesh, India. In: Thakur JK, Singh SK, Ramanathan A, Prasad MBK, Gossel W (eds) Geospatial techniques for managing environmental resources. Springer and Capital publication, Heidelberg, pp 152-163

Strahler AH (1980) The use of prior probabilities in maximum likelihood classification of remotely sensed data. Remote Sens Environ 10(2):135-163

Subedi DS, Poudel KR (eds) (2013) Application of geo-informatics on land use dynamic of Phewa LakeWatershed, Pokhara, Nepal. The Himalayan Geographers. Prithvinaryan Campus, Tribhuvan University, Pokhara

Tamrakar P, Luoma-aho T et al (2004) Status of forest genetic resources conservation and management in Nepal. Forest genetic resources conservation and management. In: Proceedings of the Asia Pacific Forest Genetic Resources Programme (APFORGEN) inception workshop, Kepong, Kuala Lumpur, Malaysia, 15-18 July, 2003. International Plant Genetic Resources Institute (IPGRI)

Tang G, Carroll RW et al (2016) Regulation of precipitation-associated vegetation dynamics on catchment water balance in a semiarid and arid mountainous watershed. Ecohydrology 9:1248-1262

Thakur JK, Srivastava PK et al (2011) Estimation of evapotranspiration from wetlands using geospatial and hydro-meteorological data. In: Thakur JK, Singh SK, Ramanathan A, Prasad MBK, Gossel W (eds) Geospatial techniques for managing environmental resources. Springer and Capital Publication, Heidelberg

Thakur JK, Srivastava PK et al (2012) Ecological monitoring of wetlands in semi-arid region of Konya closed Basin, Turkey. Reg Environ Change 12(1):133-144

UIZ (2015) Environmental Monitoring, Analysis and Interactive Visualization-EMAIV. http://uizentrum.de/en/ environmental-monitoring-analysis-and-interactive-visualization-emaiv/ van Lier HN (1998) The role of land use planning in sustainable rural systems. Landsc Urban Plan 41(2):83-91 